Günter Berghaus

Senior Research Fellow

University of Bristol
UDC 78.01:613.44

doi:10.5937/ZbAkUm1801015B

Original scientific paper

\title{
Noise: A Category in Futurist Theatre and Music
}

\begin{abstract}
Noise was a central category in Modernist art and literature as it formed an integral part of the modern urban experience and had a profound effect on the human psyche. It also became an important feature in musical aesthetics. The Futurists were amongst the first to give it a profound theoretical foundation. Luigi Russolo sought to reclaim the infinite variety of sounds found in Nature and the metropolis and to generate a new musical culture from them. Bringing together the world of music and the modern sonic environment was one of his key objectives and led him to create an orchestra of mechanical instruments - so-called intonarumori - and to present his concept of arte dei rumori in a variety of concerts and musical soirées.
\end{abstract}

Russolo's concerts and writings were widely discussed in Russia, where they fostered the development of microtonal music amongst professional composers and a materialistic conception of noise art advocated by Proletkult leaders. The substitution of conventional instrumental music with mechanical and industrial noises came to be practiced by noise orchestras and in theatrical open-air performances. Thus, the Futurist idea of joining art with life and the Marxist concept of overcoming alienation from the products of labour found a concrete realization in the musical sphere.

The Futurists' desire to liberate theatre from its subservience to the written or spoken word gave rise to a number of projects in which mechanically produced noises played a key role. One of the most successful examples was the Théâtre de la Pantomime futuriste, produced by Enrico Prampolini in 1927/28, with music composed and performed by Luigi Russolo. The performances in Paris, Turin, Bergamo and Milan transported the mechanized, modern life into the world of dance and music in a suggestive and often magical manner.

Keywords: Noise music, Futurist arte dei rumori, microtonal music in Russia, noise orchestras, mechanical instruments, mechanical dances. 


\section{The poetics of noise in Italian Futurism}

The cacophonous sounds of the street, of machines, and innumerable other, often other irksome noises form an integral part of the modern urban experience. In 1905, Ford Madox described in The Soul of London the metropolis as an „immense symphony-orchestra", whose sound is like a ,ground bass, a drone, on top of which one pipes one's own small individual melody“ (Ford, 1995: 11).

The significance of city noise to the human psyche cannot be underestimated. An Association for the Suppression of Street Noises, founded in the 1890s, wielded vigorous campaigns that were widely reported on in the newspapers of the times (Bijsterveld, 2003). A 1906 column in the Illustrated London News about the 'Nervous Age' reported that doctors were complaining to Parliament about the ,injurious effects on the nervous system produced by the excessive noise of our streets" ([Anon.], 1906). Needless to say, their effect was next to nil, and traditionalists were increasingly drowned out - pun intended - by the Modernists, who availed themselves of noise as a motive force for developing a new auditory aesthetics.

The Italian Futurist Luigi Russolo described with great clarity how the nineteenth-century population experienced the great changes in the soundscapes that surrounded them:

Life in the olden times was all but silent. In the nineteenth century, with the invention of machines, Noise was born. Today, Noise is triumphant and reigns supreme over the human sensibility. For many centuries, life unfolded in silence, or at least quietly. The loudest of noises that interrupted this silence were neither intense, nor long-lasting, nor varied. After all, if we disregard exceptional events such as earthquakes, hurricanes, storms, avalanches and waterfalls, Nature is silent. (Russolo, 1913c: 1).

This pre-industrial state of existence was radically overturned in the course of the nineteenth century. Modern industries and urban life created a raucous environment that assailed the ears of workers and city dwellers. Russolo was greatly fascinated by modernity's sonic spectrum:

When we cross a great modern capital with our ears more alert than our eyes, we will get enjoyment from [...] creating mental orchestrations of the crashing down of metal shop blinds, slamming doors, the hubbub and shuffling of crowds, the variety of din from railway stations, iron foundries, spinning mills, printing workshops, electric power stations and subways. (Russolo, 1913c: 2). 
This cacophonous new environment and the realities of modern life added new features to the infinite variety of sounds found in Nature. Blinded by the bright lights of the metropolis and deafened by the noises of its traffic, the public's sensorial perception and sensibility underwent marked changes over time. Russolo was looking for a practical reclamation of these noises and sought to create a new musical culture from them. He had the vision of making an art out of noises from the modern urban world, to gather from this sonic environment a broad spectrum of sounds, to regulate their generation by means of mechanical devices, and to introduce them into the world of concert halls. Russolo wrote compositions that were essentially an orchestration of the noises to be found in big cities, factories and theatres of war. He called his music l'arte dei rumori (the art of noises), and created mechanical devices - so-called intonarumori (noise-intoners) - that were able to produce a great variety of artificial sounds.

The Foundation and Manifesto of Futurism (1909) had presented the clamour of the modern city as a dynamic force that subverted and eventually destroyed the tranquil romantic past. Marinetti's apartment in Milan was overlooking, on the one side, the busy thoroughfare of via Senato and, on the other side, the verdant Naviglio canal. In his account, the birth of Futurism occurred when the future Futurists, engrossed in their reveries under ,star-studded, filigreed brass domes" and listening to the „tedious, mumbled prayers of an ancient canal and the creaking bones of dilapidated palaces", were suddenly hit by "the terrifying clatter of huge, double-decker trams" and ,the sudden roar of ravening motorcars, right there beneath our windows." The noise of the modern metropolis put an end to the soothing sounds of rustling waves and leaves and gave rise to an aesthetics that was inspired by ,the many-hued, many-voiced tides of revolution in our modern capitals" (Marinetti, 2006b: 11-14).

Russolo's Art of Noises was a musical equivalent to Marinetti's Futurist poetry that sought to reflect urban modernity by means of new devices: onomatopoeia, glossolalia, word fragments, neologisms, word play, telegraphic style, complex rhythms, to name but a few. As he demonstrated in his most important work, Zang tumb tuuum (1915), and in hundreds of live recitations of a poem drawn from its „Battle of Adrianople“ chapter, Marinetti's imitations of artillery noises showed how literature could be liberated from the constraints of conventional grammar and syntax, and be reduced to its most basic phonetic components. In the Technical Manifesto of Futurist Literature (1912), Marinetti insisted on the importance of noise in written representations of the harsh and strident noises to be found in urban life:

Our enemies scream at us: 'Your literature will lack beauty! We shall no longer have the symphony of words, their harmonious swaying back and forth, their soothing cadences!' [...] Indeed, we use all the ugly sounds, all the expressive cries of the violent life that surrounds us. (Marinetti, 2006a: 113) 


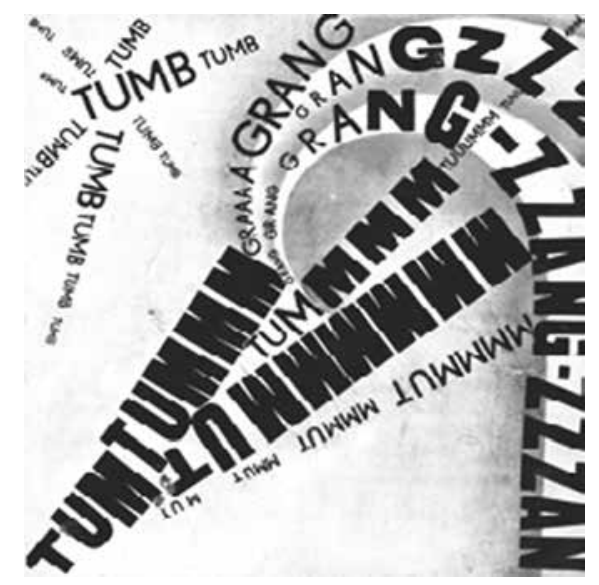

Figure 1. A page from F.T. Marinetti and Tullio d'Albisola: Parole in liberta futuriste olfattive tattili-termiche. Savona: Edizioni futuriste di poesia (Lito-Latta), 1932.

In a report on one of his many recitations of $I l$ bombardamento di Adrianopoli, at the Teatro Lírico in Rio de Janeiro on 15 May 1926, the newspaper A manhã wrote that the poet's unconventional poetry delivery was ,full of noise: battalions marching, bugles, whistles, screams, the cries of wounded soldiers, bursts of shrapnel, fusillade, roaring engines, the noise of falling buildings" ([Anon.], 1926: 9).

By exposing listeners to the noises of the modern city within the context of a concert hall, Russolo created a revolutionary form of music that also captured the sonic experience of modernity and functioned as a worthy sidepiece to Futurist literature and painting. Russolo had joined the Futurist circle as a painter, but he was also a highly accomplished pianist.' He wanted to replace the traditional concept of music with one that was based on a wide range of sounds related to, but not simply imitative of, the noises of everyday life. He condemned the tonal system in traditional music because it had a far too narrow sound spectrum. In this respect, he agreed with Francesco Balilla Pratella's critique of traditional harmonics in Futurist Music: Technical Manifesto (1911):

Whereas chromatism only lets us take advantage of all the sounds contained in a scale that is divided into minor and major semitones, enharmony contemplates still more minute subdivisions of a tone; and hence it not only furnishes our renewed

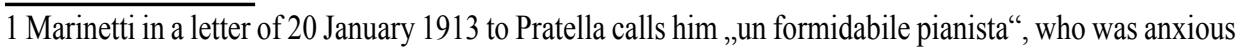
to perform Musica futurista, op. 30 (Inno alla vita) at one of the musical soirées he was planning to set up in the course of the year. See Maffina, 1980: 49. 
sensibilities with a maximum number of specifiable and combinable sounds, but also new and more varied relations among chords and timbres. (Pratella, 2009: 81)

Despite his progressive views, Pratella remained attached to many traditions in Western music. His aim was to modernize the sterile musical language that dominated the Italian musical world but not to overturn it. Russolo, in contrast, developed a musical aesthetic that went far beyond the idea of reforming the tempered system of traditional music: he sought to undertake a systematic re-organization of musical sonorities. Russolo believed that modern life had become enriched by an infinite range of new noises and that the ear of the modern big-city dweller had come to appreciate this varied soundscape in an aesthetic manner. According to him, the musical establishment had ignored the great changes in the age of industrialization and mechanization. He therefore conceived of something that was far more radical than what Pratella had outlined in his manifestos: he wanted to liberate the listening experience from conventional habits and to open up the world of music to the whole spectrum of sounds and noises. To achieve this goal, Russolo developed, together with his assistant Ugo Piatti, an orchestra of instruments that was taking Patella's idea of enharmony and chromatism to a logical conclusion.

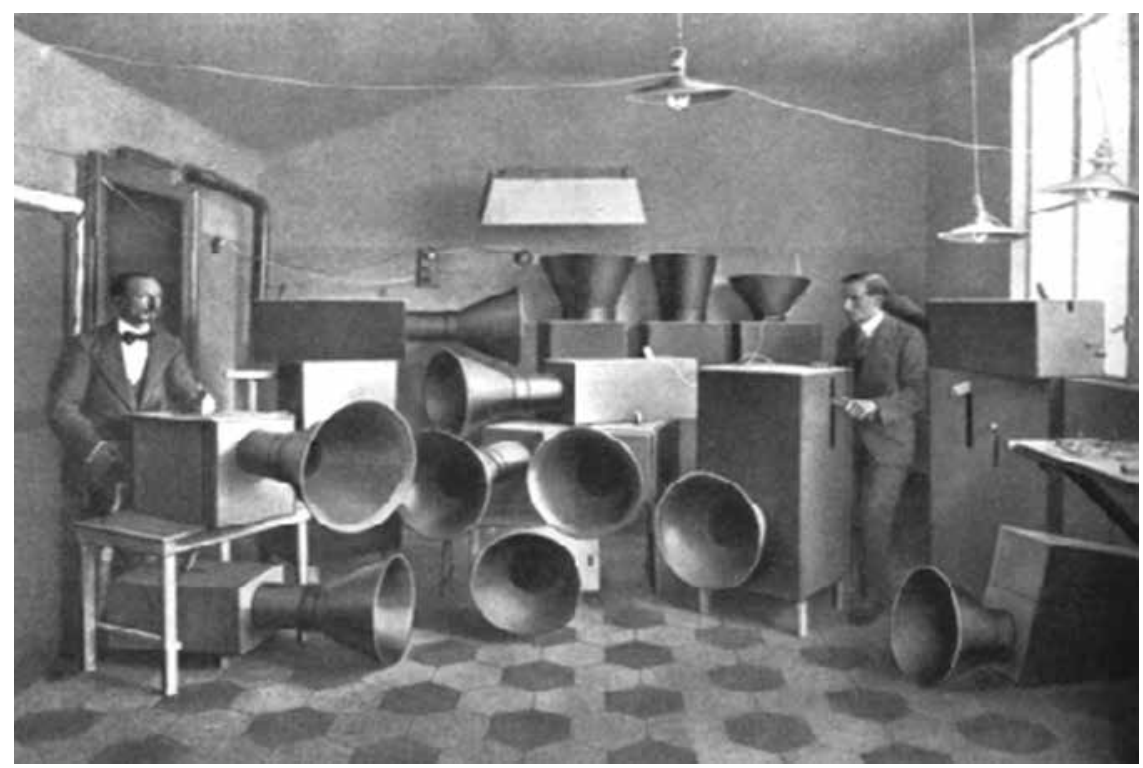

Figure 2: Russolo and Piatti with an orchestra of intonarumori, 1916

Russolo's noise generators looked like sound boxes with a large funnel attached. They produced a wide array of sonorities, which could be tuned and rhythmically 
regulated by means of mechanical manipulation. In an article for Lacerba, Russolo explained the principle behind the first such instruments:

A single stretched diaphragm, correctly positioned, will produce by variations in tension a scale of more than ten whole tones with all the divisions of semitone, quartertone and even smaller fractions. [...] Exciting the diaphragm, one obtains a different sound as to type and timbre, yet always preserving, naturally, the possibility of varying the pitch. So far we have four different means of excitation and have already completed the relative instruments. The first makes an explosive sound like an automobile engine; the second makes a crackling sound like rifle fire; the third makes a humming sound like a dynamo; the fourth makes different kinds of stamping noises. In these instruments the simple movement of a graduated lever suffices to give the noise the pitch that one wants, even in the smallest fraction. Just as easily regulated is the rhythm of every single noise, making it easy to measure the beat, be it equal or unequal. (Russolo, 1913b: 140-141)²

On 1 May 1913, Marinetti informed Pratella that Russolo had constructed, with the help of a mechanic, a machine which imitated the noise of a motor (Lugaresi, 1969: 44-45). On 31 May 1913, he would write to Palazzeschi: „On 2 June we will hold a Futurist soirée in Modena. It will be interesting, because our friend Russolo will probably demonstrate his intonarumori, on which he is working day and night, and he will explain to the audience how these instruments work" (Palazzeschi and Marinetti, 1978: 84).

\section{Russolo's mechanical noise generators in the serate futuriste}

On 2 June 1913, the Teatro Storchi in Modena was full to the last seat. ${ }^{3}$ Only few of the 2,000 spectators were familiar with the aims of the Futurist movement, but many had heard of the previous serate futuriste and had prepared themselves with a suitable array of projectiles to give Marinetti and Co. a fitting reception. The first part of the programme consisted of Marinetti explaining the principles of Futurism, Pratella presenting his ideas on the renewal of the Italian music world, and Marinetti reading a selection of Futurist poetry. After an interval, Marinetti announced the highlight of the evening: Russolo's intonarumori.

2 Russolo's progress in his research can be gleaned from the next two articles written for Lacerba: "Conquista totale dell'enarmonismo mediante gl'intonarumori futuristi" (Russolo, 1913a) and "Grafia enarmonica per gl' intonarumori futuristi” (Russolo, 1914a).

3 The serata has been described in great detail in Berghaus, 1998: 118-122. 
Russolo and Piatti brought out the first noise instrument they had constructed: the scoppiatore, which produced a sound typical of a combustion engine. The three others, crepitatore, ronzatore and stropicciatore had not been finished on time. The device was placed on a table in front of the spectators, ,like a sacred, mystic, supernatural object", wrote the Gazzetta dell'Emilia ([Anon.] 1913). However, the audience regarded the machine as something comical or even grotesque and reacted accordingly. Russolo had to consult with Marinetti on how to proceed with the show, for in the din created by the audience it was impossible to give the instrument a proper hearing. Finally, Marinetti came to the footlights and spoke about Russolo's great invention, how it was going to feature in Pratella's new opera, L'aviatore Dro, and how they were going to construct a whole orchestra of intonarumori. When, finally, Russolo and Piatti demonstrated their machine, the audience shouted: „It's all a cheat! Open the box! You are imitators and passéists! Why listen to a fake noise when we can hear the original sound every day on the street?!" ([Anon.] 1913). Apparently, the 'noise orchestra' in the auditorium drowned all the sound that issued from the instrument on stage.

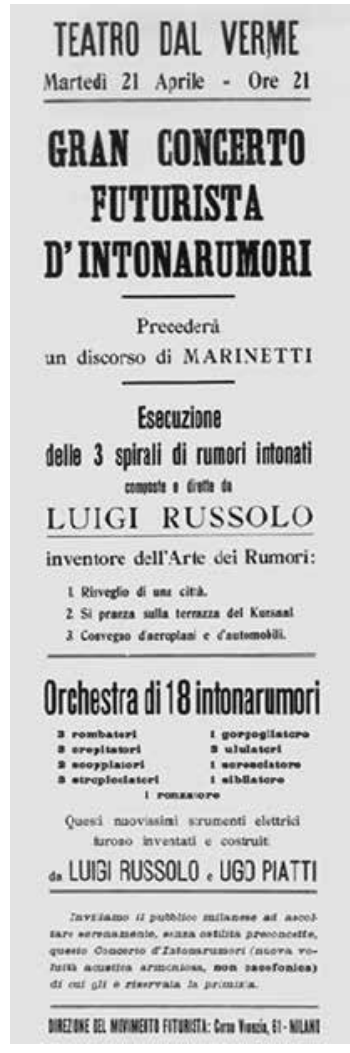

Figure 3. Poster of the Gran concerto futurista at the Teatro dal Verme in Milan, on 21 April 1914 
The première of Russolo's first urban-inspired composition, Risveglio di una città (The Awakening of a City) took place at a Gran concerto futurista at the Teatro dal Verme in Milan, on 21 April 1914. ${ }^{4}$ As in Modena, the concert proper was preceded by a theoretical introduction that did little to convince the audience of the artistic merits of the new invention. Marinetti's speech was regularly interrupted by catcalls, because Russolo's manifesto had been distributed before the concert and the audience was thus already informed about the noise instruments. When eventually the curtain rose, the audience saw on stage eighteen intonarumori ${ }^{5}$ arranged in a semicircle, and Russolo as a conductor standing on a rostrum in the middle of the orchestra. The unusual sight of the instruments prompted a round of applause and the throwing of flowers by some philo-futurists in the boxes. All newspapers agreed that there was a lively curiosity in the audience about what they were going to hear.

The three compositions that had been announced in the programme were Risveglio di una città (Awakening of a City), Colazione sulla terrazza del Kursaal Diana (Breakfast on the Terrace of Kursaal Diana) and Convegno di automobili e di aeroplani (A Meeting of Automobiles and Aeroplanes). On the poster, Marinetti had expressly stated: „We invite the Milanese public to set aside any premeditated hostility and listen quietly to the voluptuous acoustics in this first concert of intonarumori" (see Fig. 3). But as was to be expected, exactly the opposite took place. The sight of the unusual orchestra was greeted with laughter and the music was frequently interrupted by witty interjections and mocking comments (see fig. 4). Then, the situation got out of hand. Il secolo reported: „The spectators took over and began their own spectacle. They shout, sing, laugh, make a loud clatter. The first potatoes come raining down from the balcony and mingle on stage with the flowers that some Futurist lady-friends had thrown earlier on"([Anon.] 1914: 5).

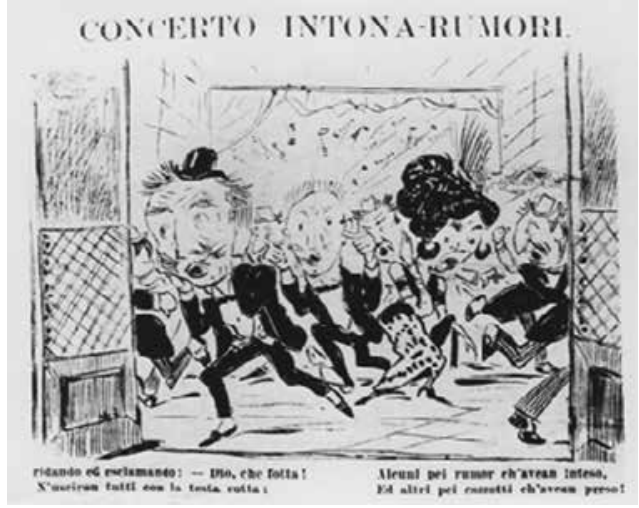

Figure 4. Caricature of the concert at the Dal Verme Theatre, 1914

4 The serata has been analysed in Berghaus, 1998: 128-133.

5 The poster (see Fig. 3) announced 18 instruments, but Russolo in L'arte dei rumori speaks of 23 (Russolo, 1916: 22). Attilio Rovinelli remembers only 12 (Rovinelli, 1953: 857). 


\section{Russian noise orchestras}

In the following months and years, Russolo gave many more concerts, not only in Italy, but also in Paris, London and various other cities. Reports on these events appeared in newspapers throughout Europe and generated a wide-spread appetite for his theoretical pronouncements. The manifesto L'arte dei rumori of 1913 was reprinted many times and also translated into various languages. The first Russian version was an abridged rendering in the theatrical magazine, Maski (Russolo, 1913/14). Soon afterwards, full versions appeared in two anthologies of Futurist manifestos published in 1914, Mikhail Engelhardt's Futurizm and Vadim Shershenevich's Manifesty ital'ianskogo futurizma. Both collections also contained Pratella's Manifesto dei musicisti futuristi. These publications came to the notice of Russian musicians and composers, as the debate entitled „Our Response to Marinetti“, which took place at the Shvedskoi Tserkvi Hall on 11 February 1914, showed. ${ }^{6}$ The composer Arthur Vincent Lourié gave a presentation on „The Music of Italian Futurism“ and juxtaposed Russolo's noise music with what Lourié called a 'genuine' form of art des bruits, i.e. microtonal music, a „music of interference: supreme chromaticism - chromo-acoustics. ${ }^{\text {"7 }}$

Lourié's distinction between noise music and microtonal organization of sound was rather vague, as he had not heard Russolo's intonarumori and could judge them only from Marinetti's lectures and Russolo's manifesto. This lack of knowledge resulted in a great deal of misunderstandings. In the mid-to late 1910s, several Russian composers (not necessarily involved in Futurist groups) experimented with microtonal systems and occasionally composed with them: Leonid Sabaneev, Mikhail Matyushin, Ivan Wyschnegradsky, Arseny Avraamov, to name but a few. However, these composers never adopted ultra-chromaticism, or introduced noise-intoners into their compositions. ${ }^{8}$ Although Russian composers were primarily concerned with reforming the tonal system, they were not indifferent to the idea of using noise in musical compositions. The earliest example is the opera Victory over the Sun of 1913, which employed not only quarter-tone notes but also propeller sounds. Besides this, in scene VI, Mikhail Matyushin indicated in his score: „Machine noise.“9

6 See ch. 5 (My i zapad) in Livshits, 1933.

7 Theses published on the poster for the Nash otvet Marinetti (Our Response to Marinetti) debate, reprinted in V. Khlebnikov, 2005: 346.

8 For a discussion of Russian noise music and microtonalism see Conti, 2008; Dudakov-Kashuro, 2016; Gojowy, 1979-1983; Gojowy, 1989; Gojowy, 1993; Mende, 2009; Smirnov, 2013.

9 The score has been published in Bartlett and Dadswell, 2010: $72-86$ and, in a Russian edition, in Matiushin, Khlebnikov, and Kruchenykh, 2015. 
According to Russolo's statements and some announcements in Russian periodicals, a concert with the intonarumori had been planned for Russia, but due to the Great War, it never took place. ${ }^{10}$ If Russians wanted to find out what the noise machines sounded like, they had to travel to Italy. In April 1915, Igor Stravinsky and Sergei Prokofiev took part in a soirée at Marinetti's apartment in Milan, in which the intonarumori were played (Berghaus, 1998: 254-255). Prokofiev published a positive assessment, „Muzykal'nye instrumenty futuristov“ in the Muzyka magazine in April 1915, and Stravinsky intended to include them in Les Noces (1923). But nothing ever came of it.

The lack of opportunities to actually hear Russolo's noise instruments led to a kind of mystique surrounding his noise music. As Konstantin Dudakov-Kashuro wrote, ,neither heard nor seen, the 'art of noises' served as a vague romantic blueprint for later proto-industrial music in theatres and film production" (Dudakov-Kashuro, 2016: 98) Russian Futurist writers, like their Italian counterparts, displayed an interest in the poetics of liberated sound. Mikhail Larionov produced in 1912 a lithograph for Khlebnikov's poem „Nash kochen' ochen' ozabochen”“ (Our cats are very concerned), in which he translated sounds into images (See Fig. 6 and Perloff, 2013). In the rather untranslatable poem of 1913, Shumiki, shumy i shumishchi, Vladimir Mayakovsky evoked city noises created by freight trains, trams, people in squares, marketplaces and tunnel passages (Maiakovskii, 1955: 54). Velimir Khlebnikov wrote in 1915 of his dream to „let factory chimneys awake and sing morning hymns to the rising sun, above the Seine as well as over Tokyo, over the Nile, and over Delhi“" (Khlebnikov, 1987: 359). In one of the earliest post-Revolutionary Futurist manifestos, Decree no. 1 about Democratization of Art: Fence Literature and Street Painting, the authors proclaimed: „Let the citizen walking down the street [...] listen to music - melodies, thunderous or noisy - of excellent composers everywhere. Let the streets be a feast of art for all“" (Maiakovskii, Kamenskii and Burliuk, 1918). The idea of a liberated sound and the pleasure of listening to all the sounds of the whole world seemed to be a natural corollary of the liberated proletariat taking possession of art and society.

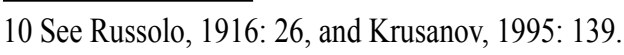

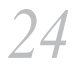




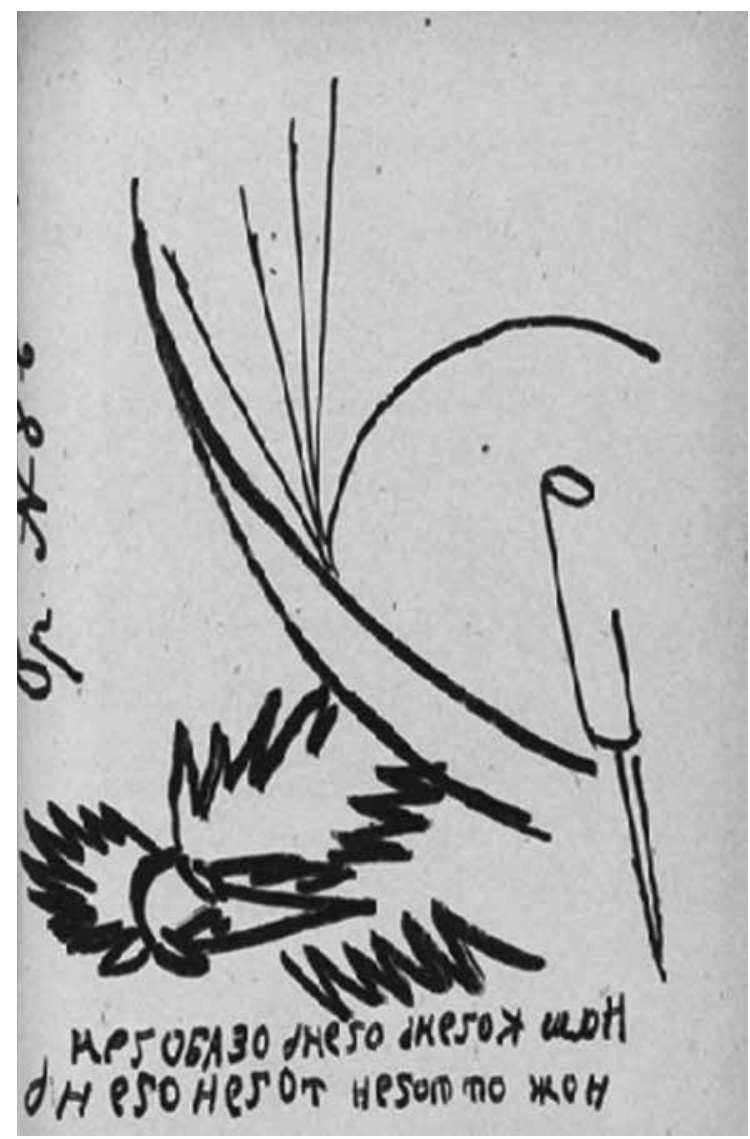

Figuration 5. Larionov: „Nash kochen.“ A page from Mirskontsa (Worldbackwards, 1912).

In a number of essays and books published between 1918 and 1923, the Proletkult leaders Boris Kushner, Valerian Pletnev and Boris Arvatov developed a materialistic conception of noise art and advocated the substitution of conventional instrumental music with industrial noises. In the near future, they believed, conventional music would become obsolete for the proletariat. As Boris Kushner pointed out, it would be replaced by an 'industrial music':

Since sound complexes may serve as a means of organizing work, and since industrial labour is, and probably will always be, closely linked to the mighty force of factory-sounds, the idea of employing acoustics for the purpose of organizing workers is a logical conclusion. One can, of course, arrange all the noises of the machines and tools, the entire sound life of the factory, in such a 
way that the sounds will exert stimulating influence on the workers' mind. With a certain stretch of the imagination, these arranged noises may perhaps be called 'the industrial music of the future'. (Kushner, 1922: 113)

Among the legendary, but not yet fully accomplished projects of those years, were the so-called Symphonies of Sirens, created and coordinated by Arseny Avraamov, a music theoretician, critic and composer. According to Avraamov in his article „Gudki“ (Factory Whistles, 1923), and some other writings, the first event in which industrial horns were musically arranged took place in Nizhny Novgorod on 7 November 1919. The event was repeated in the port of Baku, on 7 November 1922, to commemorate the Fifth Anniversary of the October Revolution. Here, it featured „a cast of choirs, the foghorns of the entire Caspian flotilla, two batteries of artillery guns, a number of infantry regiments including a machine-gun division, hydroplanes, and all the town's factory sirens" (Smirnov, 2013: 148), as well as the so-called 'Magistral', a steamwhistle device invented by Avraamov and mounted on a torpedo-boat so that the twentyfive participants of the performance could be controlled by the conductor. ${ }^{11}$

The Futurist idea of representing machine civilization in the field of sonic art extended the aesthetics of music and turned it into an organization of noise that eliminates the gap between art and life. This concept was given a theoretical foundation by Boris Arvatov in Art and Classes of 1923, where the author stated that „musicians did not want to organize artificial, non-vital sound material, but material of life as such, consisting of street and factory noises, noises of metals, wood, glass, all kinds of sounding phenomena of our everyday life, such as whistles, sirens, etc." (Arvatov, 1923: 84). Once everyday life had been transformed into art and, vice versa, life into art, the proletarian State would no longer have any need for conventional musical instruments.

However, there was also another reason for the fast growth of proletarian noise ensembles: the shortage of professionally manufactured instruments after the First World War, the Russian Revolution and the subsequent Civil War. Throughout the second half of the 1920s, musical educators such as Vladimir Dasmanov, head of the musical sector of the Georgian Proletkult, published instruction manuals and brochures for amateur ensembles who were involved in noise music (see Fig. 6). These rural and urban noise bands peaked during the late 1920s, and their repertoire included all sorts of sonic imitations of factory and Big-City noises.

11 For more detailed discussion of the Baku symphony, see Wendel, 2012. 


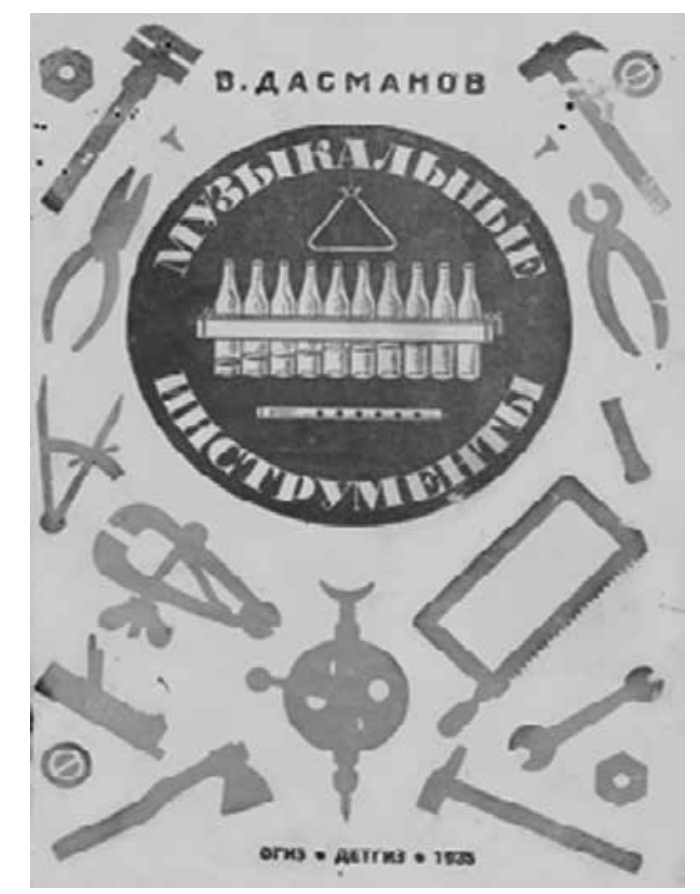

\section{Figure 6. Cover of a handbook by Vladimir Dasmanov: Muzykal'nye instrumenty (Musical Instruments, 1935).}

Another reason why workers would form musical ensembles that used materials from everyday life seems to have been related to the Marxist concept of overcoming alienation from the products of labour. These proletarian noise orchestras abolished the difference between material and cultural production, between work and leisure, between musical instruments and working tools. Closing the gap between art and life, between work and leisure, was a favourite dream of many Futurist artists. Sergei Eisenstein and Boris Yurtsev introduced noise art into their theatrical productions. In 1922/23, Eisenstein offered courses in noise music at the Moscow Proletkult (Eyzenshtein, 2005: 118), and Yurtsev published an article on „The Orchestra of Things“, in which he advocated the use of instruments made of ,assorted things and materials [...] such as bottles, pans, basins, glass, nails, needles, concrete, wood and metal, selected according to timbre and richness of sound." He suggested an „orchestra related to individual industrial sectors" and the formation of a "United Orchestra of the Central Trade-Union Council" (Iurtsev, 1922: 22). In 1924, Eisenstein directed Sergei Tretyakov's Gas Masks for Moscow's Proletkult organization. It was staged in a real gas factory, and in its last scene the arriving night shift workers ignited gas jets to the sound of factory horns, pneumatic rattles, hammers riveting huge metal sheets, etc. (See [Anon.], 1924; Gordon, 1978). 


\section{Il teatro della pantomima futurista}

During the early years of the Fascist régime in Italy, Luigi Russolo lived in Paris, where he continued to work on his concept of noise music and on new instruments that could reproduce a broad spectrum of sounds. Another Futurist then resident in Paris was Enrico Prampolini, who occupies a place of prominence in the field of Futurist theatre and can be considered one of its most eminent theoreticians. Prampolini's writings of the years 1913-15 and a great number of drawings that accompanied them presented a mechanical form of theatre that was not a photographic enlargement of a slice of life but a new scenic art. Prampolini's abstract, autonomous stage thrust aside artistic conventions and operated instead with the elements of pure form, colour, light, sound and movement. This, he believed, would eventually give rise to a form of theatre that has been liberated from its subservience to the written or spoken word.

Prampolini's stage was a dynamic, three-dimensional work of art, whose constituent elements were placed in a new order according to the rules of scenic construction. Each unit would be able to speak its own, media-specific language; but acting in unison with the others, the ensemble of scenic elements would create a dynamic whole with an unsurpassed sensual appeal to the audience. The temporal media of sound and motion would be integrated into the spatial media of colour, form and plasticity. The scenic architecture would become mobile and noise-producing, whilst the actor would take on chromatic and spatial qualities (Berghaus, 2017).

Following Prampolini's move to Paris in 1925, he established what he called a 'Ballets Italiens', to complement Sergei Diaghilev's Ballets Russes and Rolf de Marés Ballets Suédois. His co-director and financial backer was Maria Ricotti, who hired the Théâtre de la Madeleine and appointed Vladimir Golschmann as musical director. The troupe was officially called Compagnie de Pantomime Italienne and went into rehearsals in December 1926 (Berghaus, 1998: 449-468). 


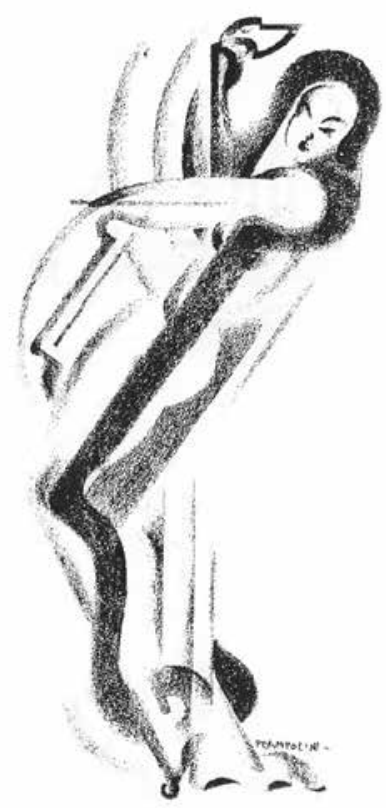

Figure 7. Wy Magito in Théâtre de la Pantomime futuriste

In the run-up to the production, Prampolini joined hands with Luigi Russolo to devise a number of pieces for the repertoire of the company. One of them was Les Trois Moments and involved Russolo's new invention, the rumorarmonio. Prampolini had created the lighting, sets and costumes and had also devised the choreography. The first tableau showed a forest with two vulva-shaped trees, from which a nymph and satyr emerge. He seduces her with his syrinx and leads her away into a modern, mechanized civilization. Scene two is set in a hotel lobby. The love play of the previous tableau is now repeated by two objects: a ventilator and a gramophone. Their amorous raptures are overheard by an elevator, who in his excitement moves frantically up and down, emanating green and red light beams from his watchful 'eyes'. Russolo's noise machines made scraping and spluttering sounds when the ventilator moved like a huge aeroplane propeller. The third scene takes place in a hotel room. The satyr and nymph have adapted to the modern lifestyle and are wearing a tail-coat and evening dress. They are assaulted by a torrent of noise coming from behind a large door at the back of the stage. The two lovers want to find out what is causing the noise and open the door. At that moment, overwhelmed by the forces they have summoned, they are sucked into the hustle and bustle of the metropolis. They leave behind two jackets on coat-hangers which in a flood of yellow light and a deluge of noise perform a foxtrot on the portmanteau. 
A revised programme of the Pantomime futuriste was performed in Turin, Bergamo and Milan in March 1928. Prampolini had appointed Franco Casavola as musical director and Wy Magito as prima donna. The rather mixed programme of the three-hour long performances included works that had proved to be particularly popular in Paris as well as various new ones, such as Ritmi spaziali, a 'phono-dance for discs', interpreted by Wy Magito, Simultaneità d'essenze (Simultaneity of Essences) and Prefazione (Preface) by Enrico Prampolini and Luigi Russolo, and Il pesce meccanico (The Mechanical Fish) by Russolo. Little is known about these new pieces, but their character can be gleaned from a résumé of the whole evening:

Magnetic lights, cubism, plastic syntheses and surprising music, and the whole programme dominated by a kind of mechanization, which distorted gestures and bodies, fixed them in suggestive geometric expressions, rearranged them all of a sudden in sharp and cutting movements as if impelled by a strident and frenzied machine or a shock from an electric discharge. ([Anon.], 1928b: 247)

When the programme was shown at the Teatro Lirico in Milan, ${ }^{12}$ the critic of the Corriere della sera was impressed with Prampolini's and Russolo's attempts to translate the world of machines into the language of sound and movement:

The music and the dances [...] evoked in our imagination contraptions and machines. They reminded us of the din of factories, the roaring noise of motors, the vertiginous frenzy of propellers. They attempted to transport the mechanized, modern life into the fragile world of dance and gesture. ([Anon.], 1928c: 251$)^{13}$

Unfortunately, the piece with which Prampolini had wanted to demonstrate an „electromechanical architecture powerfully vitalized by chromatic emanations from a luminous source" (Prampolini, 1924) was never performed. It was called Santa velocità and contained music by Casavola, to be performed on Russolo's archi enarmonichi. Prampolini explained the plot in an interview:

12 The Fondazione Primo Conti preserves a flyer which reads: „3 recital straordinari di danze della pantomima futurista, sala accademica di musica bossi, via rovello 16, 17-18 marzo." The performances were reviewed in Il secolo, 19 March, and Il popolo d'italia, 20 March 1928. Il secolo of 22 March stated that the programme was transferred, "con poche varianti, dal salone dell'accademia musicale ad un teatro".

13. L'ambrosiano of 22 March informs us that the performance was complemented by a lecture by Marinetti on Futurist stage design, and by a demonstration of Russolo's rumorarmonio. ([Anon.], 1928a: 3) 
Very modern city: a metropolis. Street lights. Cinematographic life at night, electric, dazzling. Apartment blocks. Wide streets. Sky. The only human intervention: a song which stops and then smothers the speed. When the song slowly comes to an end, the speed of modern life picks us up again in a crescendo which is extraordinary, magical, unlimited, reverberating. (Trimarco, 1928)

\section{Conclusion}

In the course of the twentieth century, noise became an important feature in musical aesthetics. The Futurists were not the first to experiment with it (see Wilson, 2014) but certainly the first to give it a profound theoretical foundation. Murray Schafer believed that bringing together the world of music and the modern sonic environment was the most striking feature of twentieth-century music (Schafer, 1994: 111). Luigi Russolo was convinced that noise should be related to everyday life and be employed to create a sonic representation of modernity. Devoting his attention to all sound instead of the limited range in traditional music, he overturned auditory habits conditioned by the sanctioned system of musical instruments. His arte dei rumori rung in a paradigm shift in our understanding of noise and brought about a profound liberation in the field of music. Thus, his bruitist aesthetics continue to have reverberations to the present day.

\section{REFERENCES:}

1. [Anon.] 1906. "The Nervous Age'." In Illustrated London News 3514 (25 August), 262.

2. [Anon.] 1913. "L'allegra serata futurista al Teatro Storchi." Gazzetta dell'Emilia (Bologna) 54(152) (3-4 June), 2.

3. [Anon.] 1914. "Serata musicale futurista: Chiassate, violenze ed arresti." Il secolo (Milano), 22 April, 5.

4. [Anon.] 1924. "Rabochii teatr Proletkul'ta: 'Protivogazy'. Iz besedy s S. Eizenshteinom.” In Zrelishcha 69, 12.

5. [Anon.] 1926. "Marinetti falou: Gritos, assobios, gargalhadas, acclamações, apotheose." In $A$ manhã (Rio de Janeiro) 119(2) (16 May 1926), 9.

6. [Anon.] 1928a. “La Pantomima futurista al Lirico.” In L'ambrosiano 71(68) (2 March), 3.

7. [Anon.] 1928b. "Teatro di Torino." La stampa (Torino), 7 March. Reprinted in Cronache del teatro futurista, edited by Giovanni Antonucci. Roma: Abete, 1975, 247-248.

8. [Anon.] 1928c. "Ultime teatrali: 'Pantomima futurista' al Lirico." In Corriere della sera (Milano), 22 March. Reprinted in Cronache del teatro futurista, edited by Giovanni Antonucci. Roma: Abete, 1975. 251-252.

9. Arvatov, Boris. 1923. Iskusstvo i klassy. Moskva: Gosizdat. 
10. Avraamov, Arsenii Mikhailovich. 1923. "Gudki." In Gorn 9, 115-116. English translation "The Symphony of Sirens (1923)." Wireless Imagination: Sound, Radio and the Avant-garde, edited by Douglas Kahn, and Gregory Whitehead, eds.: Cambridge/MA: MIT Press, 1992, 245-252.

11. Avraamov, Arsenii Mikhailovich. 1929. "Zvukovaia organizatsiia shestviia." In Iskusstvo v shkole 4, 2-6.

12. Bartlett, Rosamund, and Sarah Dadswell, eds. 2010. Victory over the Sun: The World's First Futurist Opera. Exeter: Exeter University Press.

13. Berghaus, Günter. 1998. Italian Futurist Theatre, 1909-1944. Oxford: Clarendon Press.

14. Berghaus, Günter. 2017. "Prampolini and the Theatre of the 1920s: Exhibitions of Stage Design, Mechanical Theatre, and Dance.” In Enrico Prampolini: Futurism, Stage Design and the Polish Avant-garde Theatre., edited by Przemysław Strożek. Lodz: Muzeum Sztuki, 49-58.

15. Bijsterveld, Karin. 2003. "The Diabolical Symphony of the Mechanical Age: Noise Abatement Campaigns, 1900-1940.” In The Auditory Culture Reader, edited by by Michael Bull, and Les Back. Oxford: Berg, 165-189.

16. Catrizzi, Loris. 1928. "Il teatro della pantomima futurista." In L'impero (Roma), 3 March.

17. Conti, Luca. 2008. Ultracromatiche sensazioni: Il microtonalismo in Europa, 1840-1940. Lucca: Libreria Musicale Italiana.

18. Dudakov-Kashuro, Konstantin. 2016. "Noise Music in Russian Futurism.” In International Yearbook of Futurism Studies 6, 94-118.

19. Ford, Ford Madox. 1995. The Soul of London: A Survey of a Modern City. London: Everyman.

20. Gojowy, Detlef. 1979-1983. „Arthur Lourié der Futurist.“ In Hindemith Jahrbuch 8, 147185. 12, 116-157.

21. Gojowy, Detlef. 1989. „Musikalische Ideen des russischen Futurismus.“ In Aleksandar Flaker, ed.: Glossarium der russischen Avantgarde. Graz: Droschl, 94-103.

22. Gojowy, Detlef. 1993. Arthur Lourié und der russische Futurismus. Laaber: Laaber.

23. Gordon, Mel, 1978. "Eisenstein's Later Work at the Proletkult." In The Drama Review 22(3) (September), 107-112

24. Iurtsev, Boris Ivanovich. 1922. "Orkestr veshchei." In Zrelishcha 6, 22.

25. Khlebnikov, Velimir. 1987. Collected Works. Vol. 1. Letters and Theoretical Writings. Cambridge/MA: Harvard University Press.

26. Khlebnikov, Velimir. 2005. Sobranie sochinenii v shesti tomakh. Vol. 1. Stat'i (nabroski). Uchenye trudy. Vozzvaniia. Otkrytye pis'ma. Vystupleniia (1904-1922). Moskva: Nasledie.

27. Krusanov, Andrei Vasil'evich. 1995. "Marinetti v Rossii." In Sumerki 16. 112-149. Revised in A. V. Krusanov: Russkii avangard, 1907-1932. Vol. 1. Boevoe desiatiletie. Part 2. SanktPeterburg: Novoe literaturnoe obozrenie, 2010, 98-147.

28. Kushner, Boris. 1922. "Muzyka i trud." In Gorn 6, 110-113. 
29. Livshits, Benedikt Konstantinovich. 1933. Polutoraglazyi strelets: Stikhotvoreniia, perevody, vospominaniia. Leningrad: Izdatel'stvo pisatelei. Reprint Ann Arbor/MI: University Microfilms International, 1978. English translation The One and a Half-Eyed Archer. Translated, introduced and annotated by John E. Bowlt. Newtonville/MA: Oriental Research Partners, 1977. Reprint Sankt-Peterburg: Palace Editions, 2004.

30. Lugaresi, Giovanni, ed. 1969. Lettere ruggenti a F. Balilla Pratella. Milano: Quaderni dell'Osservatore.

31. Maffina, Gianfranco, ed. 1980. Caro Pratella: Lettere a Francesco Balilla Pratella. Ravenna: Edizioni del Girasole.

32. Maiakovskii, Vladimir. 1955. "Shumiki, shumy i shumishchi." In V.V. Maiakovskii: Polnoe sobranie sochinenii v trinadtsati tomakh. Vol. 1. Moskva, Leningrad: Khudozhestvennaia Literatura, 54.

33. Maiakovskii, Vladimir, Vasilii Kamenskii, and David Burliuk. 1918. "Dekret No 1: O demokratizatsii iskusstva: Zabornaia literatura i ploshchadnaia zhivopis.” In Gazeta futuristov 1 (March). Reprinted in V.V. Maiakovskii: Polnoe sobranie sochinenii. Vol. 12. Moskva: Khudozestvennoi Literatury, 1937. 14-15.

34. Marinetti, Filippo Tommaso. 2006a. "Technical Manifesto of Futurist Literature.” In F.T. Marinetti: Critical Writings. Ed. by Günter Berghaus. New York: Farrar, Straus and Giroux, 2006. 107-119.

35. Marinetti, Filippo Tommaso. 2006b. "The Foundation and Manifesto of Futurism." In F.T. Marinetti: Critical Writings. Ed. by Günter Berghaus. New York: Farrar, Straus and Giroux, 2006. 11-17.

36. Matiushin, Mikhail, Velimir Khlebnikov, and Alexei Kruchenykh. 1913. Pobeda nad solntsem: Opera. Sankt-Peterburg: Tipografiia tovarischestva "Svet". Reprinted in Rosamund Bartlett, and Sarah Dadswell, eds.: Victory over the Sun: The World's First Futurist Opera. Exeter University Press, 2010, 46-71.

37. Matiushin, Mikhail Vasil'evich, Velimir Khlebnikov, and Aleksei Kruchenykh. 2015. Pobeda nad solntsem. CD and Booklet. Avtor vstupitel'noi stat'i Kseniia Anufrieva. Nizhnii Novgorod: Izdanie Volgo-Viatskogo filiala Gosudarstvennyi tsentr sovremennogo iskusstva.

38. Mende, Wolfgang. 2009. Musik und Kunst in der sowjetischen Revolutionskultur. Köln: Böhlau.

39. Palazzeschi, Aldo, and F. T. Marinetti. 1978. Carteggio con un appendice di altre lettere a Palazzeschi. A cura di Paolo Prestigiacomo. Milano: Mondadori.

40. Perloff, Nancy. 2013. "Mirskontsa (Worldbackwards): Collaborative Book Art and Transrational Sounds." In The Getty Research Journal 5, 101-118.

41. Prampolini, Enrico. 1924. "L'atmosfera scenica futurista." L'impero, 6-7 November. Reprinted in Prampolini: Dal futurismo all'informale, edited by Enrico Crispolti, and Rosella Siligato. Roma: Carte Segrete, 207-209. Engish translation "Futurist Scenography." Michael Stanley Kirby, and Victoria Nes Kirby: Futurist Performance. New York: Dutton, 1971. 203-2206. 
42. Pratella, Francesco Balilla. 2009. "Futurist Music: Technical Manifesto." In Futurism: An Anthology, edited by Lawrence Rainey, Christine Poggi, and Laura Wittman. New Haven/ CT: Yale University Press, 80-84

43. Rovinelli, Attilio. 1914. "La sera del 21 Aprile 1914, al 'Dal Verme'." In La martinella di Milano 7(11-12) (November-December), 856-859.

44. Russolo, Luigi. 1913a. "Conquista totale dell'enarmonismo mediante gl'intonarumori futuristi." Lacerba 1(21) (1 November), 242-245,

45. Russolo, Luigi. 1913b. "Gl'intonarumori futuristi." In Lacerba 1(13) (1 July), 140-141.

46. Russolo, Luigi. 1913c. L'arte dei rumori: Manifesto futurista. Milano: Direzione del movimento futurista, 1913.

47. Russolo, Luigi. 1913/14. "Iskusstvo shumov." In Maski 7-8, 39-46.

48. Russolo, Luigi. 1914a. "Grafia enarmonica per gl' intonarumori futuristi." In Lacerba 2(5) (1 March), 74-75.

49. Russolo, Luigi. 1914b. "Iskusstvo shumov." In Manifesty ital'ianskogo futurizma. Perevod Vadima Shershenevicha. Moskva: Tipografiia Russkogo tovarishchestva, 1914. 51-58.

50. Russolo, Luigi. 1914c. "Iskusstvo shumov." In Futurizm. Perevod Mikhail A. Engel'gardt. Sankt-Peterburg: Prometei, 1914. 130-139. 207-219.

51. Russolo, Luigi. 1916. L'arte dei rumori. Milano: Edizioni Futuriste di "Poesia".

52. Schafer, R. Murray. 1994. The Soundscape: Our Sonic Environment and the Tuning of the World. Rochester/VT: Destiny Books.

53. Smirnov, Andrey. 2013. Sound in Z: Experiments in Sound and Electronic Music in Early 20th Century Russia. London: Sound and Music.

54. Trimarco, Alfredo. 1928. "Prampolini e le pantomime futuriste a Roma." In Il mezzogiorno (Napoli), 2 February.

55. Wendel, Delia Duong Ba. 2012. “The 1922 ‘Symphony of Sirens' in Baku, Azerbaijan.” In Journal of Urban Design 4(17), 549-572.

56. Wilson, Daniel R. 2014. „The Electric Music Hall: Theatrical Inventions of the Victorian Era Rewrite the History of Electronic Music.“ The Wire 364 (June), 32-39. 


\section{Buka: Kategorija u futurističkom teatru i muzici}

Apstrakt: Buka je bila centralna kategorija u umetnosti i književnosti modernizma s obzirom na to da je bila sastavni deo modernog urbanog iskustva i imala veliki uticaj na ljudsku psihu. Postala je i značajna karakteristika muzičke estetike. Futuristi su bili među prvima koji su joj postavili duboke teoretske osnove. Luiđi Rusolo (Luigi Russolo) je težio prisvajanju neograničene šarolikosti zvukova koji se nalaze u Prirodi i metropolis, i generisanju nove muzičke kulture pomoću njih. Spajanje sveta muzike i savremenog zvučnog okruženja bio je jedan od njegovih ključnih ciljeva koji ga je podstakao da sastavi orkestar mehaničkih instrumenata - takozvani intonarumori - i da prezentuje svoj koncept arte dei rumori na raznim koncertima i muzičkim večerima.

O Rusolovim koncertima i tekstovima diskutovalo se širom Rusije, budući da su podstakli razvoj mikrotonalne muzike među profesionalnim kompozitorima kao i materijalističko poimanje umetnosti buke koje su zagovarale vođe Proletkulta. Konvencionalna instrumentalna muzika zamenjena je mehaničkom $\mathrm{i}$ industrijskom bukom i svirali su je orkestri buke i na otvorenim pozorišnim performansima. Tako je futuristička ideja spajanja umetnosti sa životom i marksističkim konceptom savladavanja otuđenosti od proizvoda rada pronašao konkretnu realizaciju u muzičkoj oblasti.

Želja futurista da oslobode pozorište od potčinjenosti pisanoj i govornoj reči pokrenula je mnogo projekata u kojima je mehanički proizvedena buka igrala ključnu ulogu. Jedan od najuspešnijih primera bio je Théâtre de la Pantomime futuriste, koji je producirao Enriko Prampolini (Enrico Prampolini) 1927/28. godine, sa muzikom koju je komponovao i izveo Luiđi Rusolo. Izvođenja u Parizu, Torinu, Bergamu i Milanu su prenela mehanizovani, moderni život u svet plesa i muzike na jedan sugestivan i često čudesan način.

Ključne reči: muzika buke, futuristička arte dei rumori (umetnost šumova), mikrotonalna muzika u Rusiji, orkestri buke, mehanički instrumenti, mehanički plesovi. 